Jusmal lemiah
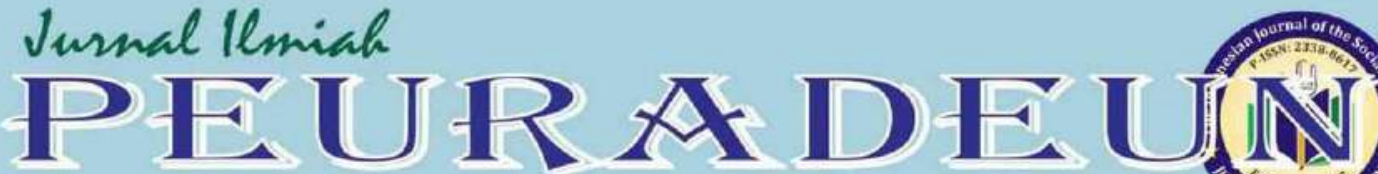

Vol. 8, No. 3, September 2020

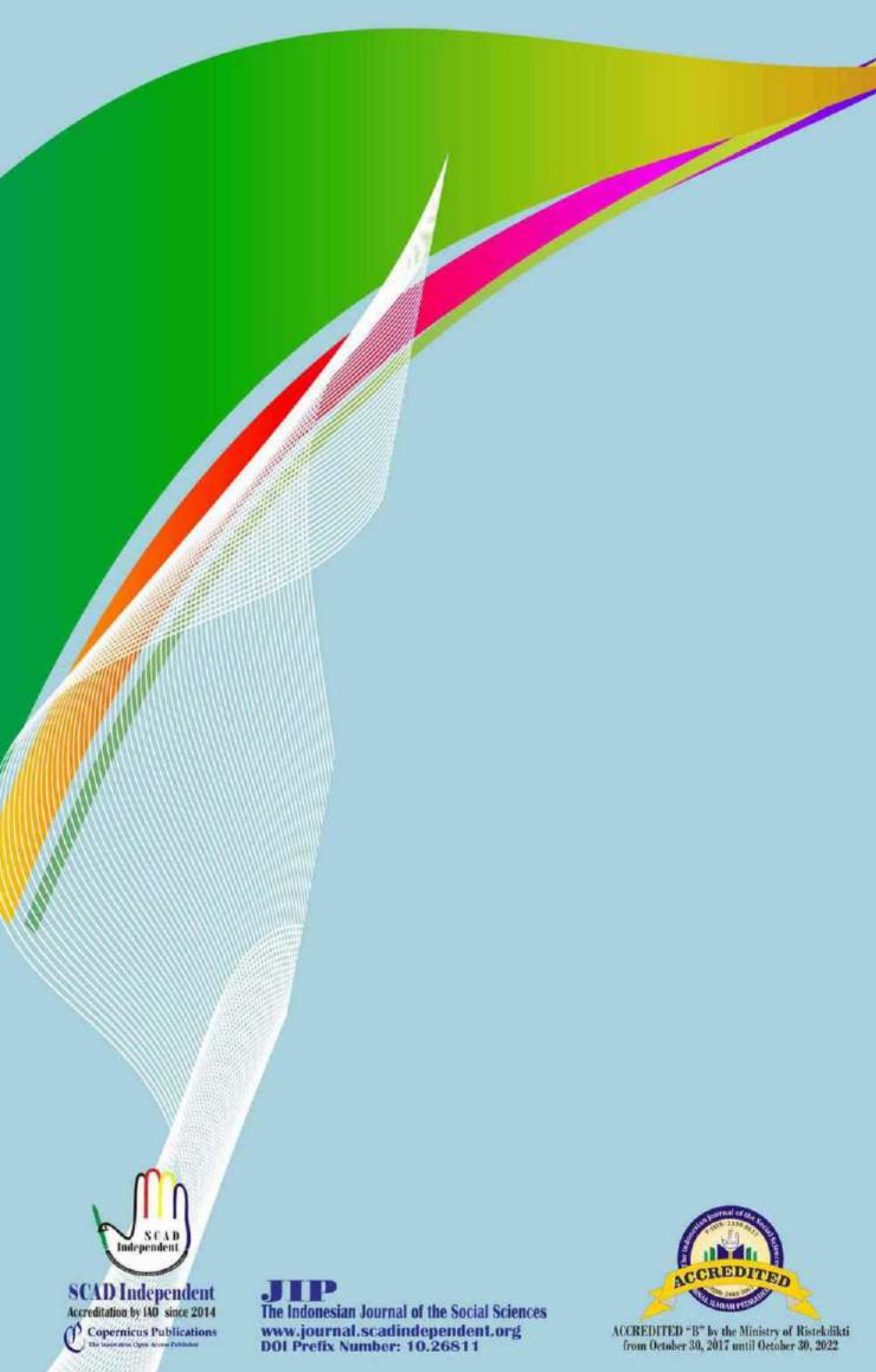

\section{Clarivate Analytics}

Emerging Sources Citation Index Web of Science ${ }^{\mathrm{TM}}$

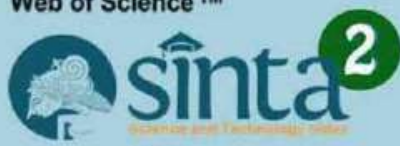

INDEX $\circledast$ COPERNICUS www.journal.scadindependent.org Dot Prefix Number: 10.2681 


\author{
JURNAL ILMIAH PEURADEUN \\ The Indanesian Journal of the Sacial Sciences \\ p-ISSN: 2338-8617/ e-ISSN: 2443-2067
}

www.journal.scadindependent.org

\author{
Vol. 8, No. 3, September 2020
}

Pages: 497-520

\title{
Self-Efficacy of the University Students' TOEFL Performance: Differences in the Test Skill and English Skills in TOEFL
}

\author{
Marisa Yoestara' ${ }^{1}$ \& Zaiyana Putri ${ }^{2}$ \\ 1,2Serambi Mekkah University, Indonesia
}

\begin{abstract}
Article in Jurnal Ilmiah Peuradeun
Available at : https://journal.scadindependent.org/index.php/jipeuradeun/article/view/386

DOI $\quad$ : http://dx.doi.org/10.26811/peuradeun.v8i3.386
\end{abstract}

\section{How to Cite this Article}

APA : Yoestara, M., \& Putri, Z. (2020). Self-Efficacy of the University Students' TOEFL Performance: Differences in the Test Skill and English Skills in TOEFL. Jurnal Ilmiah Peuradeun, 8(3), 497520. doi:10.26811/peuradeun.v8i3.386

Others Visit : https://journal.scadindependent.org/index.php/jipeuradeun

Jurnal Ilmiah Peuradeun (JIP), the Indonesian Journal of the Social Sciences, is a leading peer-reviewed and openaccess journal, which publishes scholarly work, and specializes in the Social Sciences that emphasize contemporary Asian issues with an interdisciplinary and multidisciplinary approach. JIP is published by SCAD Independent and published 3 times of year (January, May, and September) with p-ISSN: 2338-8617 and e-ISSN: 2443-2067. Jurnal Ilmiah Peuradeun has become a CrossRef Member. Therefore, all articles published will have a unique DOI number. JIP has been accredited by the Ministry of Research Technology and Higher Education Republic of Indonesia (SK Dirjen PRP RistekDikti No. 48a/KPT/2017). This accreditation is valid from October 30, 2017 until October 30, 2022.

JIP published by SCAD Independent. All articles published in this journal are protected by copyright, licensed under a CC-BY-SA or an equivalent license as the optimal license for the publication, distribution, use, and reuse of scholarly works. Any views expressed in this publication are the views of the authors and not of the Editorial Board of JIP or SCAD Independent. JIP or SCAD Independent cannot be held responsible for views, opinions and written statements of authors or researchers published in this journal. The publisher shall not be liable for any loss, actions, claims, proceedings, demand, or costs or damages whatsoever or howsoever caused arising directly or indirectly in connection with or arising out of the use of the research material. Authors alone are responsible for the contents of their articles.

JIP indexed/included in Web of Science, MAS, Index Copernicus International, Sinta, Garuda, Moraref, Scilit, Sherpa/Romeo, Google Scholar, OAJI, PKP, Index, Crossref, BASE, ROAD, GIF, Advanced Science Index, JournalTOCs, ISI, SIS, ESJI, SSRN, ResearchGate, Mendeley and others. 


\title{
SELF-EFFICACY OF THE UNIVERSITY STUDENTS' TOEFL PERFORMANCE: DIFFERENCES IN THE TEST SKILL AND ENGLISH SKILLS IN TOEFL
}

\author{
Marisa Yoestara ${ }^{1} \&$ Zaiyana Putri ${ }^{2}$ \\ 1,2Serambi Mekkah University, Indonesia \\ ${ }^{1}$ Contributor Email: marisayoestara@serambimekkah.ac.id
}

Received: Jan 29, 2019

Accepted: Dec 15, 2019

Published: Sep 30, 2020

Article Url: https://journal.scadindependent.org/index.php/jipeuradeun/article/view/386

\begin{abstract}
This study aimed at reporting differences in terms of the university students' TOEFL self-efficacy in the test skill and the English skills tested in TOEFL namely listening, structure, and reading. In conducting the study, the explanatory sequential mixed method was used as the study design, where the quantitative data from the survey was conducted first followed by the follow-up interview as the qualitative data. To collect the data in this study, a specifically designed self-efficacy questionnaire of TOEFL was distributed to the total sample of 200 university students across different disciplines from Syiah Kuala University and the University of Serambi Mekkah. The interview was then conducted with 3 selected students to have a deeper understanding of the study result. In terms of the data analysis, one-way ANOVA and $t$-test were used to describe the quantitative data, while the qualitative data was described and elaborated in words with detailed explanations. The result showed that there was a significant difference among the test skill and the English skills in TOEFL, where $F=13.61(3$, 796), $p<0.05$. The result also revealed that within the gender, only reading skill had a significant difference, where $t_{198}=-2.003, p<.005$, and within the language course participation, all the test skills and TOEFL skills were significantly different as the $p$ value of each skill was smaller than $.005(p<.005)$.
\end{abstract}

Keywords: Self-Efficacy; TOEFL; Test Skill; English Skill. 


\section{A. Introduction}

It is without a doubt that English proficiency is needed in this modern era of technology, particularly to be connected to others all over the world. Lauder (2008: 17) confirms that in Indonesia, English is instrumentally important to "provide access to the international market, scientific knowledge, and expertise". Furthermore, Sariakin (2016) also stipulates that as an international language, English's position is increasingly important in Indonesia. This is the underlying reason why English proficiency has been used as an essential requirement to determine people's future and career.

To measure people's English proficiency, an English standardized test, such as TOEFL (Test of English as a foreign language) has been continuously used in Indonesia. Therefore, the English proficiency of people is often marked by their score in TOEFL. However, according to Jahja (2016) as cited in Wurinanda (2016), at an average, Indonesians have only got 470 in TOEFL, which is less than 500 (the minimum TOEFL scores required by most universities abroad) to be able to apply for a scholarship or to work in a national and international scale company (Australian Awards in Indonesia, 2019; Samad, Jannah, \& Fitriani, 2017).

There could be several reasons underlying this low score, for example, the linguistics factors and items difficulties in TOEFL (Ananda, 2016; Snow, 1998), as well as the students' background which include motivation (Dewi, Darna, \& Suprtno, 2015) and self-efficacy (Yoestara \& Putri, 2019). Therefore, one of the contributing factors that could help in improving the students' English proficiency in TOEFL is that by improving their self-efficacy (Ish \& Rozali, 2016; Kitikanan \& Sasimonton, 2017; Mahyuddin, et al., 2006; Yusuf, 2011). Self-efficacy, itself, is defined as the self-belief owned by people which inspires the way people do the work and the way people overcome the challenge they have in completing the work (Bandura, 1995).

Furthermore, there were some other studies on the correlation between self-efficacy and test skills or each English skill. For example, a study by Chen, Casper, and Cortina (2001) confirmed that self-efficacy 
mediates the people's performance and is depending upon the task's complexity. If this study were to be connected to the TOEFL test, this could mean that when the students have a high self-efficacy in their test skills in answering TOEFL questions, they could have a good TOEFL score.

In terms of English skills in TOEFL, a study by Kitikanan and Sasimonton (2017) found that there was a significant medium correlation between the students' self-efficacy and their listening skills. Additionally, another study by Isty, Azhar, and Ras (2017) found that self-efficacy of the eighth-semester students of English Study Program FKIP-UR in the University of Riau was at the average level (180.60), and their listening comprehension was at the mediocre level (49.83). It means that the students who had higher self-efficacy had a high tendency to have a better listening comprehension score. In other words, there was a significant correlation between self-efficacy and listening comprehension.

Also, Collins and Bissell (2004) pointed out that there was a correlation between self-efficacy and grammar mastery. Their study suggested that to have good grammar mastery, the students should have a high self-efficacy, believing that they can master English grammar. Others are studies related to reading one by Kitikanan and Sasimonton (2017) that claimed a medium positive correlation, while Ningsih (2014) found a low positive correlation between self-efficacy and the students' reading capability, and that of Piran (2014) found that the reading comprehension in TOEFL was affected strongly by students' self-efficacy.

Having known that self-efficacy is an important element in helping the students reach the high TOEFL score, it is important to know the students' self-efficacy level of each skill tested in TOEFL. A study by Kitikanan and Sasimonton (2017) about the students' self-efficacy of the four English skills (but not specifically about TOEFL) revealed that second language (L2) Thai students' self-efficacy of each English language skills is relatively high and not very different among the skills. However, the study reporting about the self-efficacy in TOEFL is still very limited, particularly in Aceh, Indonesia, Therefore, this study purposes to fill in 
the gap by finding out how the actual self- efficacy level of each TOEFL skill of the university students in Aceh is.

\section{B. Theoretical Framework}

Several relevant studies about the students' self-efficacy in TOEFL have been conducted. The first one is a study by Raoofi, Tan, and Chan (2012) which revealed that several factors could improve the level of students' self-efficacy in learning the second language, thus it can be used as the predictor that can predict students' ability in mastering a second language. Based on the research findings above, it is obvious that students' self-efficacy affects their ability in language learning, including in TOEFL. Another study conducted by Genç, Kuluşaklı, and Aydın (2016) also figured out that there was a relationship between learners' selfefficacy and their beliefs in learning English.

Besides, some skill mastering (test skill and English skills) is also considered an important aspect of dealing with the TOEFL test. Manoj and Hijazi (2018) claim that by providing the appropriate strategies that suit the specific needs, which in this case is the TOEFL test, it expectedly could assist the students in achieving the target score. Moreover, equipping test takers with strategies like guessing based on the context, helping them in managing the time and exposing them with the instruction is also useful (Mousavvi \& Namdari, 2014). While Phillip (2003) as cited in Samad, Jannah, and Fitriani (2017) suggest that some reading strategies can be used in solving the problem of the TOEFL test, they are summarizing, question generating, skimming, and scanning. Those strategies are used to make the test-takers able to comprehend the reading texts in TOEFL.

Additionally, some other aspects also take part in determining the students' successes in the TOEFL test include gender (Tilfarlioğlu \& Cinkara, 2009). This aspect reportedly has a relationship with self-efficacy. However, on the contrary, Koc (2016) argues that male and female students have the same ability in understanding English text. Asgarabadi, 
Rouhi, and Jafarigohar, (2015) also state that there is no significant difference between male and female students in comprehending the English reading text. As a consequence, it is clear that there is no gender's effect in achieving the TOEFL score as long as the test takers have some preparation beforehand and have a strong belief in their ability.

In terms of language course participation, there was some study that claimed a significantly positive relationship between test preparation and performance on a standardized test such as TOEFL and IELST (Hayes \& Read, 2004; Nguyen, 2007). However, a study by Liu (2014) only found little correlation between coaching school attendance and the students' TOEFL performance.

\section{Method}

This study used an explanatory sequential mixed method design, which is defined by Creswell (2014) as the design employing collecting, analyzing, and mixing of both quantitative and qualitative data (triangulation) in a single study to provide a better understanding of the problem, but with the initial quantitative data collection followed by the qualitative data collection explaining the quantitative results. In this study, the researchers started with collecting the quantitative data by administering the self-efficacy questionnaire and followed by the qualitative data collection, which is by interviewing 3 students.

The university students in Banda Aceh (both government, Syiah Kuala University and non-government, the University of Serambi Mekkah) were the population of this study, while the total sample of this study were 200 university students (122 females and 78 male students) selected through stratified sampling method, in which a group of university students was selected if (1) they are second-year students in Syiah Kuala or the University of Serambi Mekkah (both English and NonEnglish major) and (2) have taken a TOEFL class on campus, such as TOEFL Preparation class.

The questionnaire used in this study was specifically designed by the researchers following a guide of designing a new instrument by Lietz 
(2010) and Bandura's guide of designing a self-efficacy questionnaire (Bandura, 2006). It consists of 2 parts; personal data such as gender and language course participation in the first part, and 30 items related to statements about the students' self-belief in completing the TOEFL test on the right and the number of 0-100 to measure the students' self-efficacy on the left (next to each statement) in the second part.

Statement nos. 1-5 are related to TOEFL test skill; nos. 6-18 are related to listening skills, 19-22 are about structure skills, and 23-30 are about reading skills. Meanwhile, for the interview, the researchers created 4 general questions related to the questionnaire (test skill, listening, structure, reading) which focused on "why" questions. The interview was conducted in Bahasa to get meaningful results from the students.

The result from the questionnaire was further analyzed and calculated using descriptive statistics to describe the trend of self-efficacy for each test skill and English skills in TOEFL and using inferential statistics (one-way ANOVA and t-test) to find the differences within the group (Field, 2014). Meanwhile, the result of the interview was elaborated to complete the data interpretation of the questionnaire.

\section{Results and Discussion}

\section{Results}

a. University Students' Self-Efficacy of Each TOEFL skill

1) The University Students' Test Skill Self-Efficacy

The following table displays the self-efficacy of students in the TOEFL test skill.

Table 1. Test Skill Self-Efficacy

\begin{tabular}{lcc} 
Self Efficacy Level & Frequency & Percentage \\
\hline Low (0-40) & 9 & 4,5 \\
Medium (41-70) & 129 & 64,5 \\
High (71-100) & 62 & 31 \\
Total & 200 & 100 \\
\hline
\end{tabular}

The result indicates that most students have a medium level of self-efficacy (64.5\%) and only 9 students out of 200 students have a low 
level of self-efficacy. This result is also confirmed by the qualitative findings in the interview section, where the students believe that test skill is not very frightening compared to other skills. This means that they believe that they have a medium to a high level of self-efficacy in the test skill of TOEFL.

"Sebenarnya mengetahui trik menjawab tes TOEFL itu jauh lebih mudah daripada skill lainnya" (In fact, learning to know the tips and tricks to answer the TOEFL test is far easier compared to learning other skills tested in TOEFL) (HD).

"Walaupun Saya sudah mempelajari strategi menjawab soal TOEFL, kadang kala sulit untuk menerapkan strategi tersebut ketika tes berlangsung" (Even though I have learnt the strategies to answer items in TOEFL, it is sometimes hard to apply the strategies in the real test time) (AA).

2) The University Students' Listening Skill Self-Efficacy

Table 2 shows the university students' self-efficacy in the listening skill of the TOEFL test.

Table 2. Listening Skill Self-Efficacy

\begin{tabular}{lll} 
Self Efficacy Level & Frequency & Percentage \\
\hline Low (0-40) & 32 & 16 \\
Medium (41-70) & 127 & 63,5 \\
High (71-100) & 41 & 20.5 \\
Total & 200 & 100 \\
\hline
\end{tabular}

Similar to the test skill, most students also have a medium level of listening self-efficacy in the TOEFL test, around 127 students. However, the number of students who have low self-efficacy in listening is higher than those in test skills, around $16 \%$ compared to $4.5 \%$ in test skills. The qualitative data (the interview result about the second question of TOEFL listening self-efficacy) also revealed that the students believe that they have low to medium level of self-efficacy because of the limited practice of listening and the audio in TOEFL.

"Kami jarang latihan listening TOEFL di kelas, jadi saya tidak begitu yakin saya mampu menjawab soal listening"(We rarely practice the TOEFL listening in class, so 
I am not pretty sure that I could answer the listening items in TOEFL) (HD).

"ketika tes, audionya sangat cepat. Jadi sulit memahami apa yang dikatakan" (The audio play too fast, so that it is difficult to catch what he/she says) (AA).

\section{3) The University Students' Structure Self-Efficacy}

The following table illustrates the self-efficacy of students in the structure section of TOEFL.

Table 3. Structure Self-Efficacy

\begin{tabular}{lcc} 
Self Efficacy Level & Frequency & Percentage \\
\hline Low (0-40) & 29 & 14.5 \\
Medium (41-70) & 142 & 71 \\
High (71-100) & 29 & 14.5 \\
Total & 200 & 100 \\
\hline
\end{tabular}

Self-efficacy in the structure section has a similar result with the previous two skills. However, the students with a medium level of selfefficacy are higher than the previous two skills, which is around $71 \%$. Interestingly, the students who have high self-efficacy and low self-efficacy are within the same number 29 students out of 200 students. The qualitative result about the third interview question of the students' level of selfefficacy in structure indicates that the students have high self- efficacy because they like structure. Meanwhile, those with low self-efficacy say that they could not understand and memorize the structure in English.

"Saya suka materi structure, jadi saya lebih percaya kalau saya bisa menjawab soal structure" I like structure. Hence, I believe that I could answer the structure section in TOEFL (HD)

"Saya tidak bisa menghafal rumus-rumus structure, sehingga tidak yakin bisa menjawab soal structure" I could not memorize the English structure formulas, so that I am not sure that I could answer the structure section in TOEFL. (DY).

\section{4) The University Students' Reading Skill Self-Efficacy}

The following table depicts the self-efficacy of students in the reading skill of TOEFL. 
Marisa Yoestara \& Zaiyana Putri

Table 4. Reading Skill Self-Efficacy

Self Efficacy

Level

Frequency Percentage

\begin{tabular}{lcc}
\hline Low (0-40) & 7 & 3,5 \\
Medium (41-70) & 116 & 58 \\
High (71-100) & 77 & 38.5 \\
Total & 200 & 100 \\
\hline
\end{tabular}

In the reading skill, the most dominant proportion is also those with medium self-efficacy, 58\%. However, the number of students with high selfefficacy is in the highest proportion compared to other skills, 77 students out of 200 students. The qualitative data from the interview result shows that the students have a high level of self-efficacy in reading because they think they could found the answer in the questions easily. Another student with a medium level of self-efficacy commented about the length of reading texts which influence the level of self-efficacy in the reading section.

"Saya lebih yakin menjawab soal reading di TOEFL karena saya dapat mencari jawaban pada text" (I feel more confident in answering the reading questions in TOEFL because I could find the answer right in the text) (DY).

"Saya sering khawatir tidak memiliki cukup waktu untuk menjawab soal terutama pada text reading yang panjang" (I often feel worried that I do not have enough time to answer items, especially in the long reading text ) (AA).

The following graph summarizes the university students' selfefficacy in all the TOEFL skills.

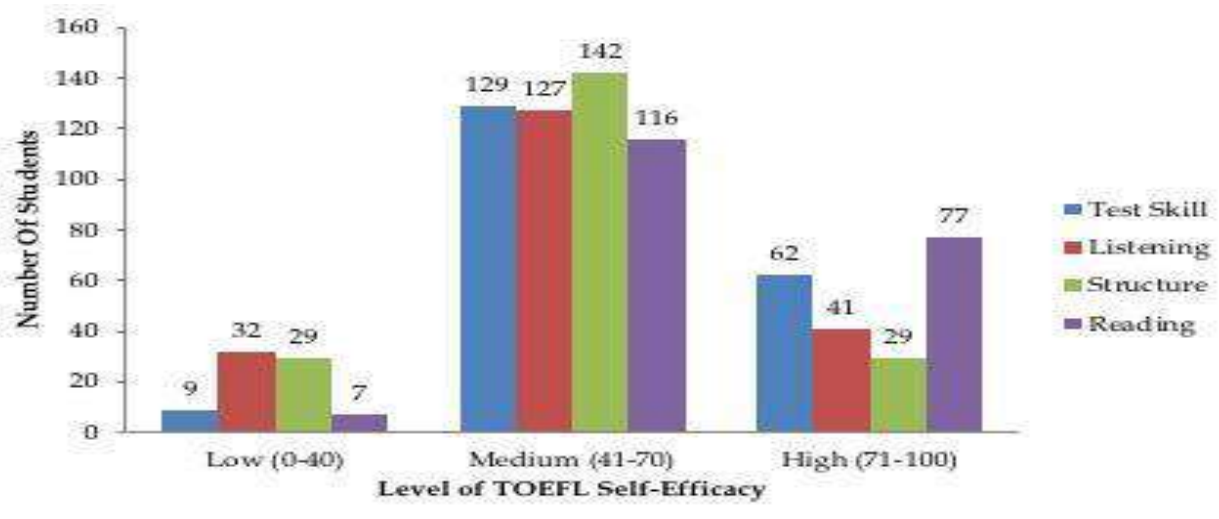

Figure 1. University Students' Self-efficacy in TOEFL skills 
From the above graph, it is obvious that above $50 \%$ of the university students in both Syiah Kuala University and the University of Serambi Mekkah have medium self-efficacy in all TOEFL skills; about $64 \%$ in both test skill and listening skill; 71\% in structure, and 58\% in reading skill. Furthermore, it is also interesting to note that the students who have a high level of self-efficacy are more than those who have low self-efficacy in all TOEFL skills. The data shows that reading skill has the highest number of students with the high level of self-efficacy, which occupies $39 \%$ of the university students, meanwhile listening and structure have the highest percentage of students with the low level of self-efficacy, which is around $16 \%$ and $15 \%$ respectively.

The interview result with the students confirms that 2 out of 3 interviewed students think that the most difficult skill tested in TOEFL is listening and structure because they rarely learn a listening skill in the secondary schools and are not used to listening to spoken English. This is as commented by the interviewees.

"...yang paling susah adalah listening karena jarang mendengar percakapan atau cerita dalam bahasa Inggris dan ketika tes, audionya sangat cepat..." (...the hardest is listening skill because I seldom listen to a dialogue or stories in English. In addition, during the test, the audio play too fast...) (AA).

“...yang paling susah adalah structure karena terlalu banyak rumus yang harus dihafal. (The hardest in TOEFL is structure because it has many formulas to be memorized) (DY).

\section{b. The Differences of the University Students' Self-Efficacy in Each TOEFL Skill}

To examine the differences in the students' level of self-efficacy based on the skills in TOEFL, Levene's Test of Equality was conducted and the result shows that the data is homogenous as the significant value is higher than $p$-value $.05, P=.068$. A one-way ANOVA was then calculated. The result revealed that there was a significant difference among the test skill and each English skill in TOEFL, where $F=13.61(3,796)$, and $p<.05$. This indicates 
that the between-group (between each skill in TOEFL) variation is about 13 times the variation within the group.

Moreover, to find out which between-groups' difference was more statistically significant; the researchers calculated Turkey's $b$ posthoc test. It was found that the self-efficacy of the reading skill was the most significantly different skill followed by test skill, listening, and structure.

\section{c. The University Students' Self-Efficacy of all TOEFL Skills in Gender}

1) The Male University Students' Self-Efficacy of all TOEFL Skills

The following figure displays male self-efficacy in the four skills of TOEFL, including test skills, listening, structure, and reading skills.

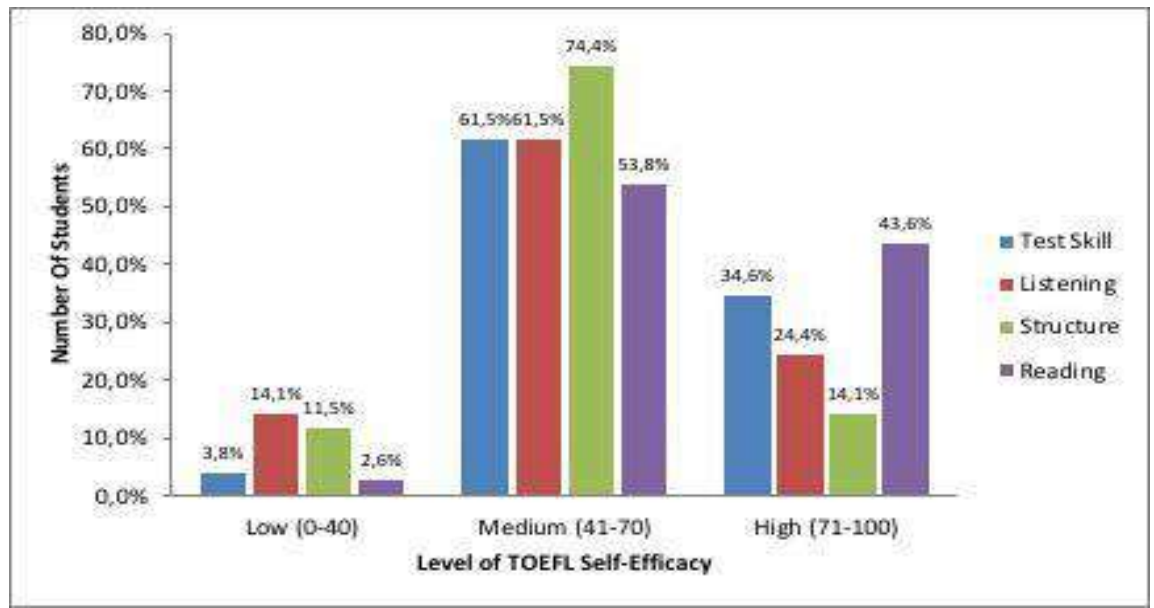

Figure 2. The Male University Students' Self-Efficacy in each TOEFL Skill

It is obvious that most male students have medium self-efficacy in all TOEFL skills, with the highest proportion in structure (around 74\%) and followed by both test skill and listening skill with the same amount $(61.5 \%)$ and reading skill (around 53\%). The male students with high selfefficacy are more and far different from those with low self-efficacy, except for structure which is only slightly different, around $11 \%$ with low self-efficacy and $14 \%$ with high self-efficacy.

2) The Female University Students' Self-Efficacy of all TOEFL Skills

Figure 3 depicts the female university students' self-efficacy of the four skills in TOEFL. 


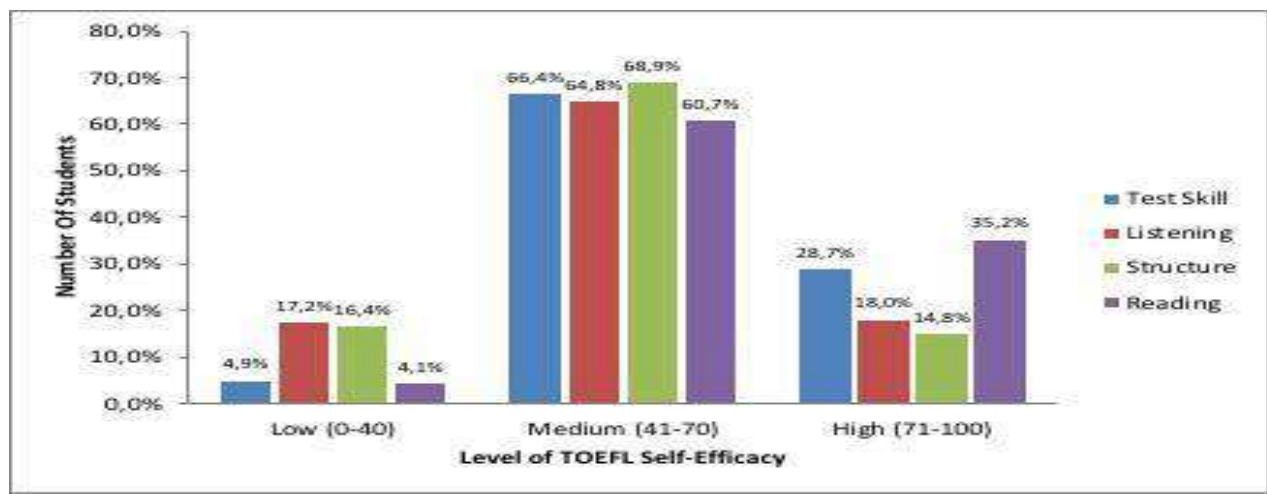

Figure 3. The Female University Students' Self-Efficacy in each TOEFL Skill

Similar to the male students' self-efficacy, most female students also have a medium level of self-efficacy with quite the same proportion of each skill, around $66 \%$ in test skill, $65 \%$ in Listening, $69 \%$ in structure, and $61 \%$ in reading. And those female students with a high level of selfefficacy are more than those with low-level self-efficacy. In the listening skill, the difference between those with high self-efficacy and those with low self-efficacy is not very far different, $18 \%$ and $17 \%$ respectively.

\section{d. The Difference of the University Students' TOEFL Self-Efficacy in Gender}

To know the gender differences in each skill, the $t$-test was conducted separately for each skill. Table 5 displays the result of selfefficacy differences in test skills according to gender.

Table 5. Independent Sample Test for Gender Differences in Test Skill

\begin{tabular}{lrcccccc}
\hline Gender & $\mathrm{n}$ & Mean & $\mathrm{SD}$ & $\mathrm{t}$ & $\mathrm{df}$ & $\begin{array}{l}\text { Lower } \\
\text { Bound }\end{array}$ & $\begin{array}{c}\text { Upper } \\
\text { Bound }\end{array}$ \\
\hline Male & 78 & 63.92 & 14.33 & - & - & - & - \\
Female & 122 & 61.85 & 14.48 & - & - & - & - \\
Total & 200 & 62.89 & 14.41 & -9.91 & 198 & -6.19 & 2.05 \\
\hline
\end{tabular}

From the statistical calculation, as shown in Table 5, it was clear that the mean difference between the two groups (male and female) in test skill is found to be $-2.07,95 \% \mathrm{CI}[-6.19,2.05]$ score units $\left(\mathrm{t}_{198}=-9.91, p>.05\right)$. It means 
that there was no statistically significant difference in TOEFL self-efficacy in test skills between male and female students, as $p=.322(p>.05)$.

The following Table 6 illustrates the result of self-efficacy for gender differences in Listening skills.

Table 6. Independent Sample Test for Gender Differences in Listening Skill

\begin{tabular}{|c|c|c|c|c|c|c|c|}
\hline \multirow[b]{2}{*}{ Gender } & \multirow[b]{2}{*}{$\mathrm{n}$} & \multirow[b]{2}{*}{ Mean } & \multirow[b]{2}{*}{ SD } & \multirow[b]{2}{*}{$\mathrm{t}$} & \multirow[b]{2}{*}{ df } & \multicolumn{2}{|c|}{$95 \%$ CI for Mean } \\
\hline & & & & & & $\begin{array}{l}\text { Lower } \\
\text { Bound }\end{array}$ & $\begin{array}{l}\text { Upper } \\
\text { Bound }\end{array}$ \\
\hline Male & 78 & 60.38 & 18.11 & - & - & - & - \\
\hline Female & 122 & 56.56 & 15.86 & - & - & - & - \\
\hline Total & 200 & 58.47 & 16.99 & -1.58 & 198 & -8.62 & .97 \\
\hline
\end{tabular}

From the statistical calculation, as shown in the table above, it was found that the mean difference between the two groups (male and female) in listening skill is found to be $-3.83,95 \%$ CI $[-8.62, .97]$ score units $\left(\mathrm{t}_{198}=-\right.$ $1.58, p>.05)$. It means that there was no statistically significant difference in TOEFL self-efficacy in listening skills between male and female students, as $p=.117(p>.05)$.

The following Table 7 shows the result of self-efficacy for gender differences in Structure.

Table 7. Independent Sample Test for Gender Differences in Structure

\begin{tabular}{|c|c|c|c|c|c|c|c|}
\hline \multirow[b]{2}{*}{ Gender } & \multirow[b]{2}{*}{$\mathrm{n}$} & \multirow[b]{2}{*}{ Mean } & \multirow[b]{2}{*}{ SD } & \multirow[b]{2}{*}{$t$} & \multirow[b]{2}{*}{$\mathrm{df}$} & \multicolumn{2}{|c|}{ 95\% CI for Mean } \\
\hline & & & & & & $\begin{array}{l}\text { Lower } \\
\text { Bound }\end{array}$ & $\begin{array}{l}\text { Upper } \\
\text { Bound }\end{array}$ \\
\hline Male & 78 & 56.85 & 14.46 & - & - & - & - \\
\hline Female & 122 & 55.75 & 14.37 & - & - & - & - \\
\hline Total & 200 & 56.3 & 14.42 & -5.27 & 198 & -5.22 & 3.02 \\
\hline
\end{tabular}

From the statistical calculation, as shown in the table above, it was found that the mean difference between the two groups (male and female) in structure is found to be $-1.10,95 \%$ CI $[-5.22,3.02]$ score units $\left(\mathrm{t}_{198}=-5.27, p>.05\right)$. It means that there was no statistically significant difference in TOEFL selfefficacy in structure between male and female students, as $p=.599(p>.05)$. 
The following Table 8 depicts the result of self-efficacy for gender differences in reading skills.

Table 8. Independent Sample Test for Gender Differences in Reading Skill

\begin{tabular}{|c|c|c|c|c|c|c|c|}
\hline \multirow[b]{2}{*}{ Gender } & \multirow[b]{2}{*}{$\mathrm{n}$} & \multirow[b]{2}{*}{ Mean } & \multirow[b]{2}{*}{ SD } & \multirow[b]{2}{*}{$\mathrm{t}$} & \multirow[b]{2}{*}{$\mathrm{df}$} & \multicolumn{2}{|c|}{$95 \%$ CI for Mean } \\
\hline & & & & & & $\begin{array}{l}\text { Lower } \\
\text { Bound }\end{array}$ & $\begin{array}{l}\text { Upper } \\
\text { Bound }\end{array}$ \\
\hline Male & 78 & 67.05 & 13.48 & - & - & - & - \\
\hline Female & 122 & 62.98 & 14.39 & - & - & - & - \\
\hline Total & 200 & 65.02 & 13.94 & -2.00 & 198 & -8.09 & -.062 \\
\hline
\end{tabular}

From the statistical calculation, as shown in Table 2, it was found that the mean difference between the two groups (male and female) is found to be $-4.08,95 \%$ CI $[-8.09,-.062]$ score units $\left(\mathrm{t}_{198}=-2.00, p<.05\right)$. It means that there was a statistically significant difference between TOEFL self-efficacy in reading skills between male and female students, as $p=.047(p<.05)$.

\section{e. The University Students' Self-Efficacy of all TOEFL Skills in Language Course}

1) Self-Efficacy in all TOEFL Skills of the University Students Participating in a Language Course

The following figure displays the self-efficacy in the four TOEFL skills of students who participated in a language course.

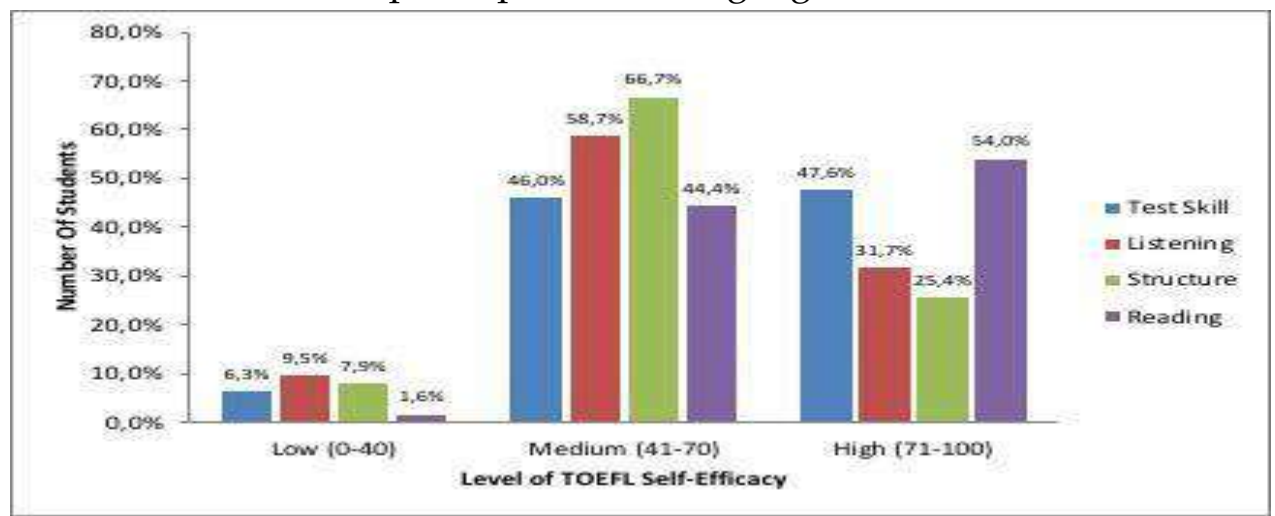

Figure 4. The Self-Efficacy in each TOEFL Skill of the University Students Participating in a Language Course 
Based on the graph, most students have a medium level of selfefficacy of all TOEFL skills. However, the students with a high level of self-efficacy are 3 times more than those with the low level of self-efficacy in all skills, with the reading skill as the highest proportion in the high level (54\%) and Listening as the highest proportion in the low self-efficacy level (around 10\%).

2) Self-Efficacy in all TOEFL Skills of the University Students Not Participating in a Language Course

The following figure displays the self-efficacy in all TOEFL skills of students who did not participate in a language course.

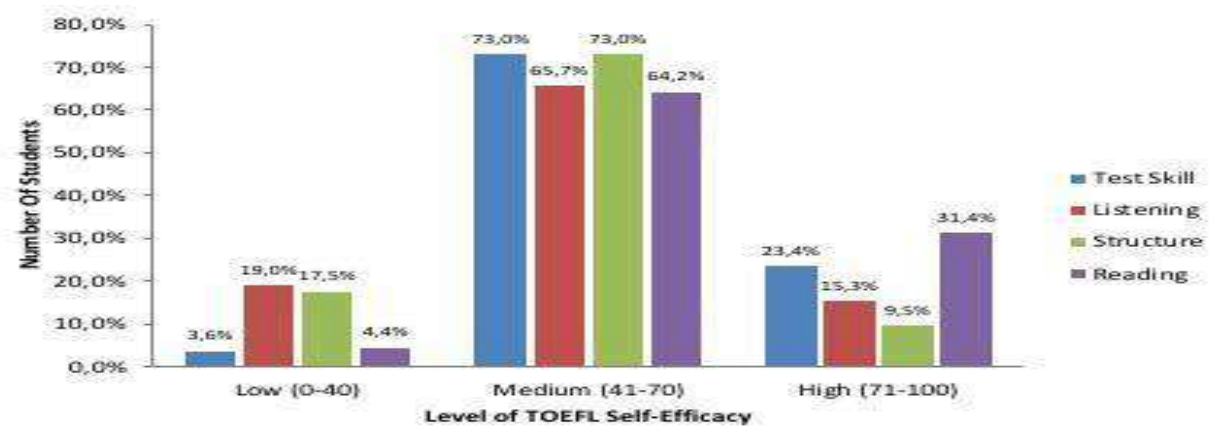

Figure 5. The Self-Efficacy in each TOEFL Skill of the University Students Not Participating in a Language Course

Similarly, most students who do not take a language course have a medium level of self-efficacy. Nevertheless, those who have a high level of self-efficacy are not too many compared to those who participated in the language course. Reading also has the highest proportion for those with high self-efficacy level, but only around 31\%.

3) The Difference of the University Students' TOEFL Self-Efficacy in Language Course Participation

To know the language course participation differences in each skill, the $t$-test was also conducted separately for each skill. The following Table 9 shows the result of self-efficacy for Language course differences in test skills. 
Vol. 8, No. 3, September 2020

Table 9. Independent Sample Test for Language Course Differences in Test Skill

\begin{tabular}{|c|c|c|c|c|c|c|c|}
\hline \multirow{2}{*}{$\begin{array}{c}\text { Language } \\
\text { Course } \\
\text { Participation }\end{array}$} & \multirow[b]{2}{*}{$\mathrm{n}$} & \multirow[b]{2}{*}{ Mean } & \multirow[b]{2}{*}{ SD } & \multirow[b]{2}{*}{$t$} & \multirow[b]{2}{*}{$\mathrm{df}$} & \multicolumn{2}{|c|}{$95 \%$ CI for Mean } \\
\hline & & & & & & $\begin{array}{l}\text { Lower } \\
\text { Bound }\end{array}$ & $\begin{array}{l}\text { Upper } \\
\text { Bound }\end{array}$ \\
\hline Yes & 63 & 67.33 & 14.59 & - & - & - & - \\
\hline No & 137 & 60.51 & 13.87 & - & - & - & - \\
\hline Total & 200 & 63.92 & 14.23 & -3.18 & 198 & -11.05 & -2.59 \\
\hline
\end{tabular}

From the statistical calculation as shown in the table above, it was found that the mean difference between the two groups (those who have participated in a language course and those who do not) is found to be $6.82,95 \%$ CI $[-11.05,-2.59]$ score units $\left(\mathrm{t}_{198}=-3.18, p<.05\right)$. It means that there was a statistically significant difference of TOEFL self-efficacy in test skills between those who have participated in a language course and those who do not, as $p=.002(p<.05)$.

Table 10 shows the result of self-efficacy for Language course differences in Listening skills.

Table 10. Independent Sample Test for Language Course Differences in Listening Skill

\begin{tabular}{lccccccc}
\hline $\begin{array}{c}\text { Language } \\
\begin{array}{c}\text { Course } \\
\text { Participation }\end{array}\end{array}$ & $\mathrm{n}$ & Mean & SD & $\mathrm{t}$ & $\mathrm{df}$ & $\begin{array}{c}\text { Lower } \\
\text { Bound }\end{array}$ & $\begin{array}{c}\text { Upper } \\
\text { Bound }\end{array}$ \\
\hline Yes & 63 & 62.59 & 16.48 & - & - & - & - \\
No & 137 & 55.96 & 16.64 & - & - & - & - \\
Total & 200 & 59.28 & 16.56 & -2.62 & 198 & -11.60 & -1.64 \\
\hline
\end{tabular}

From the statistical calculation as shown in Table, it was found that the mean difference between the two groups (those who have participated in a language course and those who do not) is found to be $-6.62,95 \%$ CI [$11.60,-1.64]$ score units $\left(\mathrm{t}_{198}=-2.62, p<.05\right)$. It means that there was a statistically significant difference of TOEFL self-efficacy in listening skills between those who have participated in a language course and those who do not, as $p=.009(p<.05)$.

Table 11 shows the result of self-efficacy for Language course differences in Structure. 
Table 11. Independent Sample Test for Language Course Differences in Structure

\begin{tabular}{|c|c|c|c|c|c|c|c|}
\hline \multirow{2}{*}{$\begin{array}{c}\text { Language } \\
\text { Course } \\
\text { Participation }\end{array}$} & \multirow[b]{2}{*}{$\mathrm{n}$} & \multirow[b]{2}{*}{ Mean } & \multirow[b]{2}{*}{ SD } & \multirow[b]{2}{*}{$t$} & \multirow[b]{2}{*}{ df } & \multicolumn{2}{|c|}{$95 \%$ CI for Mean } \\
\hline & & & & & & $\begin{array}{l}\text { Lower } \\
\text { Bound }\end{array}$ & $\begin{array}{l}\text { Upper } \\
\text { Bound }\end{array}$ \\
\hline Yes & 63 & 61.21 & 13.23 & - & - & - & - \\
\hline No & 137 & 53.86 & 14.34 & - & - & - & - \\
\hline Total & 200 & 57.54 & 13.79 & -3.44 & 198 & -11.55 & -3.14 \\
\hline
\end{tabular}

From the statistical calculation as shown in Table, it was found that the mean difference between the two groups (those who have participated in a language course and those who do not) is found to be $-7.35,95 \% \mathrm{CI}$ [$11.55,-3.14]$ score units $\left(\mathrm{t}_{198}=-3.44, p<.05\right)$. It means that there was a statistically significant difference of TOEFL self-efficacy in structure between those who have participated in a language course and those who do not, as $p=.001(p<.05)$.

The following Table 12 shows the result of self-efficacy for Language course differences in reading skills.

Table 12. Independent Sample Test for Language Course Differences in Reading Skill

\begin{tabular}{|c|c|c|c|c|c|c|c|}
\hline \multirow{2}{*}{$\begin{array}{c}\text { Language } \\
\text { Course } \\
\text { Participation }\end{array}$} & \multirow[b]{2}{*}{$\mathrm{n}$} & \multirow[b]{2}{*}{ Mean } & \multirow[b]{2}{*}{ SD } & \multirow[b]{2}{*}{$\mathrm{t}$} & \multirow[b]{2}{*}{$\mathrm{df}$} & \multicolumn{2}{|c|}{$95 \%$ CI for Mean } \\
\hline & & & & & & $\begin{array}{l}\text { Lower } \\
\text { Bound }\end{array}$ & $\begin{array}{l}\text { Upper } \\
\text { Bound }\end{array}$ \\
\hline Yes & 63 & 68.35 & 13.44 & - & - & - & - \\
\hline No & 137 & 62.82 & 14.17 & - & - & - & - \\
\hline Total & 200 & 65.59 & 13.81 & -2.60 & 198 & -9.71 & -1.34 \\
\hline
\end{tabular}

From the statistical calculation as shown in Table, it was found that the mean difference between the two groups (those who have participated in a language course and those who do not) is found to be $-5.52,95 \% \mathrm{CI}$ [9.71, -1.34] score units $\left(\mathrm{t}_{198}=-2.60, p<.05\right)$. It means that there was a statistically significant difference of TOEFL self-efficacy in reading skills between those who have participated in a language course and those who do not, as $p=.010(p<.05)$. 


\section{Discussion}

The result of this study revealed that there is a significant difference in self-efficacy in all TOEFL skills, including test skill, listening, structure, and reading skill, as the significant value $(p=.00)$ is smaller than the $p$-value .05 and $\mathrm{F}=13.61(3,796)$. This means that each university student has their own strong belief of certain skill compared to the other skills. Some students believe that they can answer more questions in reading, some others think differently. However, most students claim that they have medium to high self-efficacy in all TOEFL skills. This result is also confirmed by the qualitative findings from this research, where it was found that the students have various reasons for the low, medium, and high self-efficacy levels in different sections/skills in TOEFL.

Students with high self-efficacy commented that they have a high level of self-efficacy because they have learned tricks/strategies as the test skill, they like structure, or they could answer reading easily as the answer will be found in the text. The students with a medium level of self-efficacy stated that the TOEFL strategy learned is occasionally difficult to apply or listening is sometimes too fast. For those with a low level of self-efficacy said that they rarely practice listening, could not memorize the structure formula, and get stuck with long reading texts.

However, this research result contradicts the result from the previous study by Kitikanan and Sasimonton (2017) who claimed that Thai students' self-efficacy of each English language skills is considered high and not very different from other skills. The different results could probably be because of the different status of English in Indonesia and Thailand. In Indonesia, English is only taught at formal education and informal education, but not used daily because the status of English is a foreign language. Meanwhile, in Thailand, English is used as a second language, not only in schools but also in the conversation in daily life. Hence, Thai students would have a higher level of self-efficacy in terms of English skills.

In terms of self-efficacy of TOEFL skills in gender, the t-test result showed that only in the reading skill, male and female students differ 
significantly $p=.047\left(\mathrm{t}_{198}=-2.00, p<.05\right)$. More male students have a higher level of self-efficacy in reading (44\%) compared to female students $(35 \%)$. This also contradicts the previous findings, in which Asgarabadi, Rouhi, and Jafarigohar, (2015) found that there is no significant difference between male and female students in comprehending the English reading text. This of course needs further research to find out what makes it different. It could be linked to human character and customs in different cultures.

However, in terms of self-efficacy of TOEFL skills in language course participation, all skills are statistically different from each other, as the significant value is smaller than .05 . In the test skill, $p=.002\left(\mathrm{t}_{198}=-3.18, p<\right.$ $.05)$; Listening skill, $p=.009\left(\mathrm{t}_{198}=-2.62, p<.05\right)$; structure, $p=.001\left(\mathrm{t}_{198}=-3.44, p\right.$ $<.05)$, and reading skill, $p=.010\left(\mathrm{t}_{198}=-2.60, p<.05\right)$. This indicates that the university students who participate in the English course have higher selfefficacy compared to those who do not participate in the English course. This could probably be because taking the English course will boost the students' belief as they learn the strategies (test skill) as well as the English skill so that they could be more confident in answering the TOEFL questions. This is similar to the previous findings where Manoj and Hijazi (2018) clarified that teaching the appropriate strategies for answering TOEFL questions will help the students in answering the TOEFL test. Additionally, this result supports the findings of the previous two studies which also claim that test preparation has a positive and significant contribution to the increase of test performance (Hayes \& Read, 2004; Nguyen, 2007).

\section{E. Conclusion}

This study found that university students have different selfefficacy level of each TOEFL skills (test skill, listening, structure, and reading). The English instructors should conduct a needs analysis to know which skill should get more emphasis to help the students to improve their self-efficacy to influence the improvement in the TOEFL Score.

Furthermore, it was found that self-efficacy in reading skills have a significant difference between male and female. The stressing of teaching 
reading should be placed on females to increase their self-efficacy. Finally, in terms of language course participation, as a significant difference was found in all TOEFL skills, it is suggested that the students take a language course as the preparation step to improve their self-efficacy before taking the TOEFL test.

\section{Bibliography}

Agri, D., Berry, A., Arandia, J., \& Anastasia, E. (2018). Framework for Analysing Educational Equity in the English Education System. Jurnal Ilmiah Peuradeun, 6(2), 339-358. doi:10.26811/peuradeun.v6i2.303

Ananda, R. (2016). Problems with Section Two ITP TOEFL Test. Studies in English Language and Education, 3(1), 35-49.

Asgarabadi, Y. H., Rouhi, A., \& Jafarigohar, M. (2015). Learners' Gender, Reading Comprehension, and Reading Strategies in Descriptive and Narrative Macro-Genres. Theory and Practice in Language Studies, 5(12), 2557-2564.

Australian Awards in Indonesia. (2019). Retrieved from https://www.australiaawardsindonesia.org/index.php/content/1 $58 / 12 /$ general-requirements?sub=true.

Bandura, A. (1995). Self-Efficacy in Changing Societies. New York: Cambridge University Press.

Bandura, A. (2006). Guide for Constructing Self-Efficacy Scales. In F. Pajares \& T. Urdan (Eds.), Self-Efficacy Beliefs of Adolescents (pp. 307337). Greenwich, CT: Information Age Publishing.

Chen, G., Casper, W. J., \& Cortina, J. M. (2001). The Roles of Self-Efficacy and Task Complexity in the Relationships among Cognitive Ability, Conscientiousness, and Work-Related Performance: A Meta-Analytic Examination. Human Performance, 14(3), 209-230.

Collins, S. J., \& Bissell, K. L. (2004). Confidence and Competence among Community College Students: Self-Efficacy and Performance in Grammar. Community College Journal of Research \& Practice, 28(8), 663-675.

Creswell, J. W. (2014). Educational Research: Planning, Conducting and Evaluating Quantitative and Qualitative Research (4th ed.). Boston: Pearson. 
Dewi, I. I., Darna, D., \& Suprato, D. (2015). The Changes of Students' TOEFL Score after One Year Learning. Humaniora, 6(4), 507-519.

Erizar, E., \& Azmi, M. (2017). The Effectiveness of English Teaching Module at Middle Schools in West Aceh. Jurnal Ilmiah Peuradeun, 5(3), 333-340. doi:10.26811/peuradeun.v5i3.150

Field, A. (2014). Discovering Statistics Using IBM SPSS Statistics (4th ed.). London: Sage.

Genç, G., Kuluşaklı, E., \& Aydın, S. (2016). Exploring EFL Learners' Perceived Self-Efficacy and Beliefs on English Language Learning. Australian Journal of Teacher Education, 41(2), 53-68.

Hayes, B., \& Read, J. (2004). IELTS Test Preparation in New Zealand: Preparing Students for the IELTS Academic Module. In L. W. Cheng, Y. J. Watanabe \& A. Curtis (Eds.), Washback in Language Testing: Research Contexts and Methods (pp. 97-111). Mahwah, NJ: Erlbaum.

Ish, R. A. E. S., \& Rozali, Y. A. (2016). Hubungan Self-Efficacy dengan Prestasi Belajar pada Peserta Mata Kuliah TOEFL 2: Studi pada Mahasiswa Angkatan 2014 Reguler Aktif di Semester Ganjil 2015/2016 Universitas Esa Unggul. (The Correlation between Self-Efficacy and Learning Achievement of TOEFL 2 Students: A Study of 2014 Regular and Active Students in Odd Semester 2015/2016 of Esa Unggul University) Unpublished Undergraduate thesis. Universitas Esa Unggul - Jakarta. Retrieved from http://digilib.esaunggul.ac.id/hubungan-selfefficacy-dengan-prestasi-belajar-pada-peserta-mata-kuliah-toefl-2studi-pada-mahasiswa-angkatan-2014-reguler-aktif-di-semesterganjil-20152016-universitas-esa-unggul-7108.html.

Isty, R. A., Azhar, F., \& Ras, F. (2017). Correlation between Self-Efficacy and the Listening Comprehension of the Eighth-Semester Students of English Study Program FKIP-UR. Jurnal Online Mahasiswa Fakultas Keguruan dan Ilmu Pendidikan Universitas Riau, 4(2), 1-5.

Kitikanan, P., \& Sasimonton, P. (2017). The Relationship between English Self-Efficacy and English Learning Achievement of L2 Thai Learners. Language Education and Acquisition Research Network (LEARN) Journal, 10(1), 148-163.

Koç, D. K. (2016). The Role of Gender in Reading Comprehension: An Analysis of College-Level EFL Students'Comprehension of Different Genres. International Online Journal of Education and Teaching, 3(3), 218-227. 
Lauder, A. (2008). The Status and Function of English in Indonesia: A Review of Key Factors. Seri Sosial Humaniora (Social Humanities Series), 12(1), 9-20.

Lietz, P. (2010). Research into Questionnaire Design: A Summary of the Literature. International Journal of Market Research, 52(2), 249-272.

Liu, O. L. (2014). Investigating the Relationship between Test Preparation and TOEFL iBT@ Performance. ETS Research Report Series (RR-1415, p. 1-13). Princeton, NJ: Educational Testing Service.

Mahyuddin, R., Elias, H., Cheong, L. S., Muhamad, M. F., Noordin, N., \& Abdullah, M. C. (2006). The Relationship between Students' SelfEfficacy and Their English Language Achievement. Jurnal Pendidik dan Pendidikan, 21, 61-71.

Manoj, S \& Hijazi, S. (2018). Test Preparation Strategies for the TOEFL Can Be Diverse and Effective. International Journal of ELT, Linguistics and Comparative Literature, 6(1), 5-9.

Mousavi, S. A., Arizavi, S., \& Namdari, N. (2014). The Effect of Test Preparation on the Test Performance: The Case of the IELTS and TOEFL iBT Reading Tests. International Journal of English and Education, 3(2), 10-22.

Nguyen, T. N. H. (2007). Effects of Test Preparation on Test Performance: The Case of the IELTS and TOEFL iBT Listening Tests. Melbourne Papers in Language Testing, 12(1), 1-23.

Ningsih, T. K. (2014). The Correlation between Self-Efficacy and Reading Comprehension of Second-Grade Students at SMAN 1 Moro Karimun Regency. Unpublished Undergraduate Thesis. State Islamic University of Sultan Syarif Kasim - Pekan Baru.

Philips, D. (2003). Longman Preparation Course for the TOEFL Test. London: Longman.

Piran, N. A. (2014). The Relationship between Self-Concept, Self-Efficacy, Self-Esteem, and Reading Comprehension Achievement: Evidence from Iranian EFL Learners. International Journal of Social Sciences $\mathcal{E}$ Education, 5(1), 58-66.

Raoofi, S., Tan, B. H., \& Chan, S. H. (2012). Self-Efficacy in Second/Foreign Language Learning Contexts. English Language Teaching, 5(11), 60-73. 
Samad, I. A., Jannah, M., \& Fitriani, S. S. (2017). EFL Students' Strategies Dealing with Common Difficulties in TOEFL Reading Comprehension Section. International Journal of Language Education, 1(1), 29-36.

Sariakin, S. (2016). Model-Based Development of English Language Learning Characters in Improving Students Achievement of SMA. Jurnal Ilmiah Peuradeun, 4(2), 173-182.

Snow, M. S. (1998). Economic, Statistical, and Linguistic Factors Affecting Success on the Test of English as a Foreign Language (TOEFL). Information Economics and Policy, 10(2), 159-172.

Tilfarlioğlu, F. Y., \& Cinkara, E. (2009). Self-Efficacy in EFL: Difference among Proficiency Groups and Relationship with Success. NovitasRoyal, 3(2), 129-142.

Usman, M. (2015). Teaching Model of Learning English Writing at University. Jurnal Ilmiah Peuradeun, 3(3), 441-450.

Wurinanda, I. (March 10, 2016). Rata-Rata Skor TOEFL di Indonesia dibawah 500 (The Average Indonesian TOEFL Score below 500). Retrieved from https://news.okezone.com/read/2016/03/10/65/1332176/ratarata-skor-toefl-di-indonesia-di-bawah-500.

Yoestara, M. \& Putri, Z. (2019). University Students' Self-Efficacy: A Contributing Factor in TOEFL Performance. SIELE (Studies in English Language and Education), 6(1), 117-130.

Yusuf, M. (2011). The Impact of Self-Efficacy, Achievement Motivation, and Self-Regulated Learning Strategies on Students' Academic Achievement. Procedia Social and Behavioral Sciences, 15, 2623-2626. 
p-ISSN: 2338-8617 